Article

\title{
Towards A Situated Urban Political Ecology Analysis of Packaged Drinking Water Supply
}

\author{
Michelle Kooy ${ }^{1,2, *}$ and Carolin T. Walter ${ }^{2}$ \\ 1 Integrated Water Systems \& Governance, IHE-Delft Institute for Water Education, 7 Westvest, \\ 2611 AX Delft, The Netherlands \\ 2 Department of Human Geography, Planning and International Development, University of Amsterdam, \\ Nieuwe Achtergracht 166, 1018 WV Amsterdam, The Netherlands; carolintinawalter@gmail.com \\ * Correspondence: m.kooy@un-ihe.org or m.e.kooy@uva.nl; Tel.: +31-015-215-1814
}

Received: 31 October 2018; Accepted: 23 January 2019; Published: 29 January 2019

check for updates

\begin{abstract}
The inclusion of packaged drinking water (PDW) as a potentially improved source of safe drinking water under Goal 6.1 of the Sustainable Development Goals (SDG) reflects its growing significance in cities where piped water has never been universal or safe for drinking. Using the case of PDW in Jakarta, Indonesia, we call for theorizing the politics of PDW through a situated Urban Political Ecology (UPE) analysis of the wider urban water distributions in which it is inserted. We do so in order to interrogate the unevenness of individual "choices" for securing safe drinking water, and highlight the ambiguity of PDW's impact on inequalities in access. We first review research on PDW supply to specify how dominant theoretical approaches used for understanding PDW supply through analyses of the individual making "choices" for drinking water are power neutral, and why this matters for achieving equitable water access. We illustrate these points through a case study of PDW consumption by low income residents in Jakarta, and then identify how a situated UPE framework can help attend to the uneven societal relations shaping different socio-material conditions, within which individual "choices" for PDW are made. For Jakarta, connecting choices of the individual to power relations shaping geographies of urban water access and risk explains the rise in PDW consumption by low income residents as a situated response to the uneven exposure of poorer residents to environmental hazards. We conclude with reflections on how this can inform interventions towards more just distributions of safe drinking water.
\end{abstract}

Keywords: urban water infrastructure; political ecology; water governance; water quality; packaged drinking water (PDW); bottled water; Jakarta; Indonesia

\section{Introduction: The Growth of Packaged Drinking Water Supply}

In 2008, packaged drinking water (PDW) became the drinking water supply for the majority of residents in the Indonesian capital city district of Jakarta [1]. Since then, reliance on PDW for safe water supply has increased, so that in 2017, 72\% of households reported drinking PDW, $15 \%$ drink groundwater, and $14 \%$ drink piped water [2]. Although Jakarta surpasses national trends in the consumption of PDW, consumption of PDW for all of Indonesia has grown at more than $12 \%$ annually over 2009-2014 [3], is used by more than 40\% of the country's urban residents, and an increasing number of low-income residents [4]. This has led the World Bank to identify the rise in PDW consumption as the defining trend of the Indonesian water sector over the last 15 years, making the statement that although more households in Indonesia now have access to piped water, they are not drinking it, especially in cities [4] (p. 14).

The rise in consumption of PDW by lower income residents of Indonesia's cities illustrates global water and development trends, where the growth of PDW as a source of drinking water supply is 
documented in cities where improved water sources from the tap or the ground have never met drinking water quality standards or been universally accessible. Despite the emergence of PDW in the urban water landscapes of what the International Bottled Water Association terms "developing economies" over the last decade [5], the study of PDW as a form of water supply is only recent. Most social science studies of PDW explain this phenomenon as a commercial product, a luxury, and a source of waste-not as a source of supply [6-9]. Where PDW is studied as a water supply, largely in contexts where access to improved sources is not universal, or safe for drinking, research is overwhelmingly focused on the water quality of this supply [10]. Research on PDW quality has increased awareness of the role of PDW as a source of water supply in contexts where the majority of the world's urban residents live-cities where piped water is not universally accessible, or safe for drinking without prior point of use treatment [11]—and have reinforced the importance of water quality as a dimension of equitable water access [12,13].

However, as we go on to argue, the explanatory frameworks used in the disciplines conducting the vast majority of research on PDW supply are only able to provide a partial, and what we identify as a-political, understanding of PDW. This, we contend, conceals how PDW supply might redress or reproduce the unevenness of water access or water related risks. We explain this analytical gap as the result of the dominant approach to understanding PDW supply through an analysis of the individual making "choices" for PDW supply, disconnected from the wider societal processes and social relations shaping choices. We argue this power neutral analysis delimits understanding of how PDW supply relates to urban water inequalities to what can be identified through the individual (affordability, health impacts), and therefore addressed through the individual (improving choices). Alternatively, it acknowledges-and then closes off for investigation-the identification of power relations and societal processes shaping individual choices in what are termed "governance failure", or "gaps in service provision'". As a result, the current dominant understandings of PDW supply do little to acknowledge the politics of PDW supply-what uneven power relations it responds to, and what this means for reproduction or contestation of these inequalities. Here is where we suggest a (re)theorizing of PDW supply can benefit from a situated Urban Political Ecology (UPE) analysis. This approach holds power relations as central to explain how and why urban residents live in vastly unequal conditions - with differential access to water and exposure to environmental hazards-and what this means for the unevenness of choices on how to secure safe drinking water. Towards this, we build on recent calls for a situated UPE analysis of the politics of urban water, decentering the piped network as an object through which to analyze both how power shapes distributions of water, and as an axis upon which inequalities are defined [14-16].

We develop these arguments for why it is important to understand PDW supply through an analysis of the wider politics of urban water distributions through the case of Jakarta, Indonesia. We take Jakarta as an example of one of many cities where access to piped water has never been universal or safe, and the consumer choice for PDW is not one made between tap and bottle, but between a variety of sources and providers. We anchor our analysis of the conceptual and practical limitations of understanding PDW supply through frameworks of individual choice in existing practices of household water supply-how PDW supply is used, by whom, and in what combinations with other flows of water in the city. Our documentation of these practices draws on empirical data collected in Jakarta over different periods from 2014-2017, and includes household water supply surveys, PDW consumer surveys, interviews with key informants in national and provincial government agencies, and international development partners. Our identification of the politics of choices for securing safe water concealed by dominant explanations for PDW supply is supported by empirical data collected over this period, but is also informed by our previous research on the politics of water supply in the city $[14,17-19]$ 


\section{Situating Explanations of PDW Supply}

In this section, we review the current research on PDW in cities where PDW exists within a variegated water provisioning landscape. We document how PDW has been studied as a consumer product, and as a form of supply, in order to discuss how a situated UPE analysis of urban water distributions enables a (re)theorization of the politics of this supply.

Much of what is known about PDW in cities where the universal provision of drinking water from the tap has never been the norm is through the study of PDW as a consumer product, rather than a form of supply. Consumer research reports assess the contours of the PDW market in various regions to establish who the individual consumers are, what type of water they consume, and how much-in the Philippines [20], Indonesia [3,21], Jordan and Lebanon [22], and globally [5,23]. Reports on the shift of the global market for PDW to lower- and middle-income countries mirror the documentation of demographic trends, noting rise in household consumption of PDW in water and development sector reports, such as in Indonesia [4], Mexico [24], and Lao [25].

Understanding PDW as a consumer product uses consumer analyses to explain the rise in PDW consumption in these countries. Here, analysis of the influence of advertising and marketing strategies on individual perceptions of water quality [26] mirrors the approach to understanding PDW in the west, where historically, universal provision of water has meant PDW is not understood as a form of supply, but as a consumer product. In her 2017 review on bottled water research, Hawkins identifies the question dominating research globally on bottled water as "why consumers choose PDW over piped water" [27] (p. 3). She also notes that answers to this question have been concentrated in disciplines of business studies and psychology, investigating how marketing strategies have contributed to this expansion of a product which could be had for "free" from the tap [22,28-31].

Findings from consumer reports in "emerging economies" have explained consumption-or choices-of individuals for PDW in relation to a range of individual level factors. However, interestingly, the significance of income level in predicting consumption patterns is not conclusive. For Jakarta, this has set up certain paradoxes, as the poorest residents of a city are amongst those who "choose" the highest per unit volume source of water [19]. Consumer studies show that income level is not the most important or key individual factor shaping choices for PDW in Jakarta [32], Manila [20], Bandung [33], and Accra [34]. These results challenge the understanding of PDW as a result of consumer habits driven by rising income of a growing middle class [23]. Explaining what then drives consumption of PDW, if not income, has led to an even more detailed focus on the individual consumer to explain PDW supply. Stoler documents a growing evidence base of micro-consumer studies for West Africa, where an increased specification of who is consuming explains what are identified as "choices" in drinking water as a "budding evidence base regarding microeconomic consumer trends that have helped us better understand who drinks sachet water, where, and what individual level factors shape their choices" [12] (p. 4).

The shift from understanding PDW as a consumer product, to one of understanding PDW as a form of supply, has been largely driven by public health research. Like consumer analyses, public health research has overwhelmingly focused on the water quality of PDW, but quality is used to analyze impact of consumption on health of individuals, rather than the influence of advertising or marketing. This early focus of public health researchers on PDW was driven by concerns over health implications. In many cities where PDW is consumed across income levels, there are variations in quality within an essentially self-regulating domestic PDW market. Stoler highlights variations in quality for sachet water in Accra [13]; Sharma and Bhaduri flag that contamination events are under-reported in Delhi [10]; and online media documents contamination events are still occurring in Indonesian cities [35]. However, over the years, as general conclusions seem to be that quality of PDW is improving through self-regulation of the domestic industry (for Indonesia, see World Bank, 2015 [4]; for West Africa, see Stoler (2017) [12], public health research has highlighted the significance of PDW as form of supply in contexts where it is of superior quality to other "improved" sources. A recent systematic review of global research on PDW water safety concluded PDW products are 
substantially less likely to be contaminated than alternative water sources for consumption, including piped water [36]. Public health scholars have also documented better quality of PDW in comparison to other point-of-use treatment options (boiling, ceramic, solar disinfection), which are, for variety of reasons, not adopted, or not applied correctly [37].

This focus on the quality of PDW supply and health impacts has shown how choices for safe drinking water are both more limited, and more heterogeneous, in cities where there has never been universal access to safe drinking water. As there is no "choice" to make between drinking water from the tap or drinking PDW—-because tap water is either not accessible, or not safe for drinking-it is thus problematic to understand PDW only as a consumer product. However, although public health research has shown how choices of individuals are influenced by the contexts in which they are made-what other options are available, and to whom-it can do little to analyze how the unevenness of these contexts, and the choices made in them, are shaped by power relations. Public health, like consumer studies, focuses on the individual to explain choices, and subsequent health outcomes-choices of how to secure safe water are understood through an analysis of the individual's knowledge of disease transmission, attitudes, and hygiene practices. In Indonesia, Nastiti et al. (2017) identify choices of low-income households for PDW supply as a health risk aversion strategy informed by individual level, rather than societal, factors [33]. In Accra, Ghana, public health research, which aimed to understand PDW supply through analysis of both individual and community level factors, still rooted its four hypotheses explaining choices for PDW in the analysis of the individual: demographics, water knowledge, attitudes, and other individual level factors [34].

This also means that the understanding of PDW supply generated by public health research is power neutral, or what we identify as a-political. As choices for how to secure safe drinking water are understood through the analysis of the individual, they remain disconnected from wider societal processes or social relations. While public health is unable to ignore the limited options for safe drinking water, given their own research results, they are unable to interrogate the unevenness of choices, or impacts of choices, beyond a frequent reference to the "gap" in provision of piped water. This "gap in service provision" is what both public health researchers and consumer studies often default to for explanations of limited choices [12,26]. For consumer analyses, these gaps in service provision are included through the analysis of the individual-how PDW responds to consumer preferences for water quality, convenience, or perceptions of affordability [32,38]. For public health, societal inequalities are observed through the individual level factors shaping consumption, such as distance to improved water source. Explanations of gaps in service provision are often limited to the concept of governance failure [12,26]. This explanation tends to be power neutral, as gaps are seen as the inability of government to provide potable water to all, rather than any particular exclusions or inequalities in access shaped by power relations (exception: [34]). Conclusions tend to identify good governance as a remedy for "gaps in service provision" correcting the "missed opportunities" [12] (p. 2), rather than acknowledging how distributions of water to one place comes at the expense of reduced quantity and quality for other places.

Here is where UPE analysis of urban water distributions can contribute to understanding of PDW supply, offering analytical tools to build on existing understandings of PDW supply based on analysis of the individual. Specifically, it can attend to how "gaps" in provision-and thus responses to these gaps-are produced by uneven social relations and societal processes beyond the individual. Documenting the heterogeneity of water supply and infrastructure, UPE researchers point out that heterogeneity is not neutral. For example, research in Lilongwe $[39,40]$ documents how differences in water quality provided by the piped network are shaped by the social relations through which maintenance practices occur, so that lower income areas of the city have poorer quality of piped water. Recognizing the unevenness of conditions in which choices for how to secure safe drinking water are made indicates these social relations are not power neutral-they reflect power differences. How this unevenness is produced demands grappling with questions of power and politics, and connects PDW supply to broader politics of urban water supply. A UPE approach to understanding PDW supply 
thus calls attention to how "choices" are shaped by the relations of power, producing uneven existing distributions of both water and water related risk across the city.

The limitations of an approach to understanding PDW supply through water quality or the individual have been noted before, but represent a very small sample of the research contributing to our understanding of PDW supply. In 2014, Sharma and Bhaduri showed how notions of purity (suspicion of tap water quality) or scarcity (gaps in service provision), cited by individuals as reasons for PDW use in Delhi, are shaped by broader sets of social relations [10]. They conclude that understanding PDW supply requires a more nuanced analysis [10] (p. 6) of the societal processes creating different conditions across the city. This observation has also been made for understanding PDW supply in Accra, as Morinville (2017) calls for discussions of sachet water in Accra to acknowledge the deeply political nature of water access in Accra, and uses a UPE analysis to show how choices of individuals are shaped by the different geographies of water access [41].

We agree with these previous observations of the politics of PDW supply, while noting the importance of situating analyses of the politics of urban water distributions, within which PDW is inserted [16]. While choices for PDW supply are shaped by the uneven social relations producing heterogeneous piped water service delivery [41], they are also shaped by flows of water and power not contained by infrastructure. For Jakarta, as we turn to document, situating analysis of urban water politics entails recognizing how connections between power and groundwater and piped water create uneven geographies of urban risk [14], and generates different kinds of choices by individuals on how to secure safe drinking water.

\section{Research Design}

We anchor our call to (re)theorize the politics of PDW supply within the existing water supply practices of low income households in Jakarta. Our analysis of how PDW is used, by whom, and in what combinations with other flows of water in the city draws on quantitative and qualitative data collected as part of a study on water access by the urban poor conducted from 2014-2017. The data collection conforms to the Amsterdam Institute of Social Science Research ethics principles (All households, consumers, and water sector personnel interviewed verbally indicated their informed consent prior to the survey or interview being conducted, following an explanation of the project and information being collected, and a guarantee of maintaining the anonymity of respondents, following the principles of voluntary participation in research, safety in participation, privacy, and trust [42]. Situating our analysis of individual household PDW consumption within the uneven geographies of access in which they are consumed draws on qualitative data collected over 2015-2017, and is supplemented by previously published historical analyses of the politics of the city's water infrastructure.

We analyze quantitative data drawn from two sets of household surveys. A first round of survey data on water supply was collected from April to November 2014 in three sub-districts (Kelurahan): Penjaringan, in the North Jakarta municipality, and Gedong and Ciracas, in the East Jakarta municipality ('Survey A'; $\mathrm{n}=189$ ). The sample was taken from lower-income neighborhoods (Rukun Warga/RW) in these sub-districts, identified through interviews with the sub-district heads and staff of development organizations working in these areas. A second round of data collected between July and December 2015 ('Survey B'; $n=80$ ) specifically targeted customers of refill PDW in Penjaringan, Gedong, and Kampung Tengah—the latter location replacing Ciracas, for reasons of ease of accessibility.

The 2014 survey instrument documented household income, household water sources, volumes used per source and per unit, monthly expenses per water source, and mechanism of access. Data was collected by means of a stratified sample $(n=189)$, with 104 surveys collected in the southern locations (Gedong $\mathrm{n}=55$ and Ciracas $\mathrm{n}=49$ ) and 85 in the north (Penjaringan). The 2015 PDW customer survey recorded socioeconomic status, water sources accessed, and perceptions of price and quality of these sources. A total of $n=80$ questionnaires was collected, 40 of which in Penjaringan and another 40 in Gedong and Tengah. Households were chosen by means of a systematic-sampling 
procedure from lists of customers from 12 refill water depots, with households randomly chosen from the 12 PDW providers. The providers were chosen through a purposeful sample of low-income neighborhoods in the sub-districts and identified through interviews with the local administrative leaders (Rukun Warga / Rukun Tetangga leaders), and interviews with corporate social responsibility program staff of dairy company Frisian Flag (Jakarta, Indonesia), which runs a water supply, sanitation, and hygiene program in the three sub-districts.

We purposefully selected low income neighborhoods in Jakarta to document these practices and explore the societal relations through which they can be explained. We did so given our concern with equitable water access; it is neighborhoods like these where PDW supply may increase inequalities in access based on affordability, raising percentage of monthly income spent on water supply above $5 \%$ [19]. But it is also in these neighborhoods where the identification of PDW supply as and increasing inequality seems to provide little explanation for why residents are increasingly "choosing" PDW for supply. Perhaps most significantly, neighborhoods like these are the ones where the inequalities that PDW choices might respond to are being ignored by current water sector interventions who document, but fail to see the relevance of, use of PDW supply by households newly provided with access to piped water. We also take these research sites in Jakarta as representative for other low-income urban areas across Indonesia, where consumption of PDW is growing rapidly.

Sub-district Penjaringan is located along the coastline of Jakarta Bay. Although the socio-economic status of the district is improving, it has historically had a very high density of both legally occupied low-income communities, and illegal informal settlements along the riverside and under toll roads. The research sites in the south-eastern area of Jakarta (sub-districts Gedong, Kampung Tengah, and Ciracas) are all adjacent sub-districts geographically located in the southern half of Jakarta, but administratively part of the East Jakarta municipality. These districts became urban as the city expanded in the 1980s and land use changed from agricultural to residential and commercial.

Geographical conditions related to household water supply differ between the two areas. Penjaringan is low-lying and flood prone; given its coastal location, the shallow sub-surface groundwater is saline. In sub-districts Gedong, Kampung Tengah, and Ciracas, shallow sub-surface groundwater is still fresh and used for consumption and non-consumption purposes. For piped water access, Gedong, Ciracas, and Kampung Tengah are served by PT. Aetra, a private sector water supply company covering the eastern half of Jakarta. In Penjaringan, piped water supply services are supplied by PT. PAM Lyonnaise Jaya (PALYJA) (Jakarta, Indonesia), the private sector water supply company responsible for the Western half of the city. All the residents surveyed in these areas have a KTP (Kartu Tanda Penduduk, citizenship card) and can show proof of PBB (Pajak, Bumi, and Bangunan), a land and building tax payment receipt, except when the respondents are renters. Residents who have these documents are eligible for a piped water connection on their premise.

\section{Understanding PDW Supply in Low Income Neighborhoods of Jakarta}

\subsection{Practices of Household Water Supply}

We start with documenting the practices of PDW consumption in our research sites: who uses, how much, and what kind, and in what combinations with other sources. Our household survey (A) in 2014 found the majority of households (77\%) surveyed in the northern and southern research sites consume at least one form of PDW (refill and/or branded) (Table 1). As Survey B sampled for refill PDW users, all of the participants consumed PDW. 
Table 1. Mean monthly household income, poverty level, and PDW consumption per data collection round and research location. (Source: Authors)

\begin{tabular}{|c|c|c|c|c|c|c|c|c|c|}
\hline & $\begin{array}{c}\text { Average } \\
\text { Household } \\
\text { Income * }\end{array}$ & $\begin{array}{c}\text { Share of } \\
\text { Households } \\
\text { below poverty } \\
\text { Line }\end{array}$ & $\begin{array}{c}\text { Share of } \\
\text { Households } \\
\text { Consuming } \\
\text { PDW } * *\end{array}$ & $\begin{array}{c}\text { Average } \\
\text { Household } \\
\text { Income* }\end{array}$ & $\begin{array}{c}\text { Share of } \\
\text { Households } \\
\text { below poverty } \\
\text { Line }\end{array}$ & $\begin{array}{c}\text { Share of } \\
\text { Households } \\
\text { Consuming } \\
\text { PDW }{ }^{* *}\end{array}$ & $\begin{array}{c}\text { Average } \\
\text { Household } \\
\text { Income* }\end{array}$ & $\begin{array}{c}\text { Share of } \\
\text { Households } \\
\text { below poverty } \\
\text { Line }\end{array}$ & $\begin{array}{c}\text { Share of } \\
\text { Households } \\
\text { Consuming } \\
\text { PDW * }\end{array}$ \\
\hline \multirow{2}{*}{ Survey A } & \multicolumn{3}{|c|}{ Penjaringan } & \multicolumn{3}{|c|}{ Gedong and Ciracas } & \multicolumn{3}{|c|}{ Total } \\
\hline & $4.77(352.03)$ & 50.58 & 82.35 & $5.17(381.55)$ & 50.96 & 76.92 & $\begin{array}{c}4.99 \\
(368.26)\end{array}$ & 50.79 & 79.37 \\
\hline \multirow{2}{*}{ Survey B } & \multicolumn{3}{|c|}{ Penjaringan } & \multicolumn{3}{|c|}{ Gedong and Kampung Tengah } & \multicolumn{3}{|c|}{ Total } \\
\hline & $3.69(272.32)$ & 67.50 & 100 & $4.13(304.79)$ & 57.50 & 100 & $3.90(287.82)$ & 62.50 & 100 \\
\hline
\end{tabular}


Household income is comprised of all incomes of the individual household members plus other one-time monthly incomes where applicable. Using the poverty line (4.4 IDR/household/month) for Jakarta favored by the Ministry of Planning and Development (BAPPENAS) (Jakarta's official poverty line, as set by the Indonesian Central Bureau of Statistics' (BPS), is IDR 2.15 million or USD 158 per household per month. At an average household size of four [43], this translates to just above USD 1.40 per person per day and lies, therefore, even below the internationally used USD 2 per person per day cut off. Walter et al. [32] and Deny [44] explain how this measurement is contested and inaccurate, we find between $50.79 \%$ and $62.50 \%$ of households surveyed in this study are under the poverty line. As shown in Table 1, the average incomes of households in the PDW consumer survey are marginally lower than in the 2014 sample, since the former focused more specifically on low-income neighborhoods in the research locations. Nevertheless, both sets of results confirm the socio-economic status of the survey population as "poor".

Both surveys indicate that most households choose either branded PDW or domestically produced refill PDW, rather than combining the two (Table 2). Refill PDW (air isi ulang) is priced at around 5000 Indonesian rupiah (IDR) (USD 0.37) per $19 \mathrm{~L}$, three times less expensive than brand name PDW, which is sold on average at IDR 15,000 (USD 1.11) per $19 \mathrm{~L}$. Refill water is typically provided by small-scale water entrepreneurs, of which there are over 8000 estimated to be operating in Jakarta. Refill water providers purify groundwater on premises through various membrane-based filter systems, following delivery of bulk water trucked into the city from nearby springs. These are often family run businesses, owned and operated by residents who live in the neighborhoods they serve. What we call branded PDW is the bottled water produced by large corporations in an industrial production process [26]. Along with the difference in cost with refill water, there is also a difference in how water quality is regulated; branded bottled water quality is regulated by the Consumer Protection Agency, and refill water quality is regulated by the Ministry of Health, through random water quality analyses by sub-district health offices.

Table 2. Overview of PDW consumption patterns in northern and southern research locations according to type (a), purpose (b), and quantity (c). (Source: Authors)

\begin{tabular}{|c|c|c|c|c|c|c|c|}
\hline & & \multicolumn{2}{|c|}{ Penjaringan } & \multicolumn{2}{|c|}{$\begin{array}{c}\text { Gedong and Ciracas } \\
\text { (A)/Kampung Tengah (B) }\end{array}$} & \multicolumn{2}{|c|}{ Total } \\
\hline \multicolumn{8}{|c|}{ a) PDW USE: TYPE (SURVEY A) * } \\
\hline \multicolumn{2}{|c|}{ Refill PDW only } & \multicolumn{2}{|c|}{14.12} & \multicolumn{2}{|c|}{23.08} & \multicolumn{2}{|c|}{19.04} \\
\hline \multicolumn{2}{|c|}{ Branded PDW only } & \multicolumn{2}{|c|}{64.71} & \multicolumn{2}{|c|}{47.12} & \multicolumn{2}{|c|}{55.02} \\
\hline Combination re & Ided & \multicolumn{2}{|c|}{3.53} & \multicolumn{2}{|c|}{6.73} & \multicolumn{2}{|c|}{5.29} \\
\hline Tota & & \multicolumn{2}{|c|}{82.35} & \multicolumn{2}{|c|}{76.92} & \multicolumn{2}{|c|}{79.37} \\
\hline \multicolumn{8}{|c|}{ b) PDW USE: PURPOSE (SURVEY B)* } \\
\hline Drinking & & \multicolumn{2}{|c|}{35} & \multicolumn{2}{|c|}{7.5} & \multicolumn{2}{|c|}{21.25} \\
\hline Home enter & & \multicolumn{2}{|c|}{5} & \multicolumn{2}{|c|}{0} & \multicolumn{2}{|c|}{2.5} \\
\hline Drinking an & & \multicolumn{2}{|c|}{45} & \multicolumn{2}{|c|}{67.5} & \multicolumn{2}{|c|}{56.25} \\
\hline Cooking and ho & prise & \multicolumn{2}{|c|}{0} & \multicolumn{2}{|c|}{5} & \multicolumn{2}{|c|}{2.5} \\
\hline Drinking and ho & prise & \multicolumn{2}{|c|}{7.5} & \multicolumn{2}{|c|}{0} & \multicolumn{2}{|c|}{3.75} \\
\hline Drinking and cooking & e enterprise & \multicolumn{2}{|c|}{7.5} & & & & \\
\hline & & c) 1 & W USE: VC & JME ** & & & \\
\hline & & Survey A & Survey B & Survey A & Survey B & Survey $A$ & Survey B \\
\hline & Average & 179.00 & 123.44 & 117.38 & 95.64 & 148.19 & 109.54 \\
\hline Branded PDW & Minimum & 19.00 & 50.40 & 19.00 & 30.00 & 19.00 & 30.00 \\
\hline & Maximum & 608.00 & 172.80 & 304.00 & 152.00 & 608.00 & 172.80 \\
\hline & Average & 131.07 & 312.36 & 231.28 & 196.84 & 181.18 & 254.60 \\
\hline Refill PDW & Minimum & 57.00 & 76.00 & 19.00 & 76.00 & 19.00 & 76.00 \\
\hline & Maximum & 465.00 & 2128.00 & 570.00 & 1368.00 & 570.00 & 2128.00 \\
\hline
\end{tabular}

Note: * in percentages, as share of total households ** in liters, per household per month.

In the sites we surveyed, PDW is used most commonly for drinking and cooking and the volume of PDW consumed per household per week ranges from between $19 \mathrm{~L}$ and $532 \mathrm{~L}$. For households who only use PDW for drinking or cooking only (77.5\% of all surveyed households), the range is between 38 
to $57 \mathrm{~L} /$ week. This corresponds to two to three "gallons" (of $19 \mathrm{~L}$ each) of refill PDW/household/week, or $1.23 \mathrm{~L} /$ person/day to $1.85 \mathrm{~L} /$ person/day, using an average household size of four.

None of the surveyed households rely on PDW as their only water source (Table 3). PDW supply is combined with what the Government of Indonesia classifies as "improved domestic sources" — shallow groundwater or piped water supply. The equation of these sources as "improved" in terms of accessibility and safety is problematic, as noted by other researchers, as they still require treatment at point-of-use level before drinking.

Nastiti (2017) notes that despite the adjustments made within water and development goals in the SDGs, the Indonesian criteria for what constitutes an improved source has not changed very much since the MDGs-categories of improved versus unimproved are still associated with the type or source of water, rather than the quality of service provision [33] (p. 138). The Indonesian government specifies the " $4 \mathrm{~K}$ " criteria for improved sources in Indonesia (kuantitas or quantity, kualitas or quality, kontinuitas or continuity, keterjangkauan or accessibility), but the household survey instrument used to calculate the percentage of households with access to an "improved domestic source" asks households about the type of water source used, rather than laboratory measurements of the water quality of the source.

In Survey A, we found the majority of households accessing an improved domestic source through piped water, either directly or indirectly, consume PDW. Households who access groundwater as an improved domestic source were less likely to consume PDW.

Table 3. Household water combinations, in percentages (Survey A). (Source: Authors).

\begin{tabular}{cccc}
\hline Source & Penjaringan & $\begin{array}{c}\text { Gedong and } \\
\text { Ciracas }\end{array}$ & Total \\
\hline Piped water & 10.59 & 3.85 & 6.88 \\
Piped water + branded PDW & 37.65 & 19.23 & 27.51 \\
Piped water + refill PDW & 4.71 & 15.38 & 10.58 \\
Piped water + branded PDW + refill PDW & 2.35 & 5.77 & 4.23 \\
Piped water (total) & $\mathbf{5 5 . 2 9}$ & $\mathbf{4 4 . 2 3}$ & $\mathbf{4 9 . 2 1}$ \\
Nyelang water & 7.06 & 0 & 3.17 \\
Nyelang water + branded PDW & 27.06 & 0 & 12.17 \\
Nyelang water + refill PDW & 9.41 & 0 & 4.23 \\
Nyelang water + branded PDW + refill PDW & 1.18 & 0 & .52 \\
Nyelang (total) & $\mathbf{4 4 . 7 1}$ & $\mathbf{0}$ & $\mathbf{2 0 . 1 1}$ \\
Piped water (direct + indirect) & $\mathbf{1 0 0}$ & $\mathbf{4 4 . 2 3}$ & $\mathbf{6 9 . 3 1}$ \\
Groundwater & 0 & 18.27 & 10.05 \\
Groundwater + branded PDW & 0 & 26.92 & 14.81 \\
Groundwater + refill PDW & 0 & 7.69 & 4.23 \\
Groundwater (total) & 0 & 0.96 & 0.52 \\
Groundwater + branded PDW + refill PDW & $\mathbf{0}$ & $\mathbf{5 3 . 8 5}$ & $\mathbf{2 9 . 6 3}$ \\
Piped water + groundwater & 0 & 0.96 & 0.52 \\
Piped water + groundwater + branded PDW & 0 & 0.96 & 0.52 \\
\hline
\end{tabular}

In survey A, almost 75\% of households consuming PDW for drinking combined this with piped water (direct or indirect access) and 25\% combined use of PDW with shallow groundwater (Table 4). This reflects the national trends noted by the World Bank in 2015; more households have physical access to piped water, but they are not drinking it. Examining the two research sites separately, we find that all PDW consuming households in Penjaringan access piped water as the improved domestic source, but only $55 \%$ of these households have a direct connection to piped water, while the rest resort to piped water from indirect connections (Nyelang). An indirect connection refers to buying piped water from neighbors with a direct connection to the piped water network. In Gedong and Ciracas, households combine PDW with both piped water and groundwater. 
Table 4. Combinations of water sources from PDW-consuming households (percentages, Survey A). (Source: Authors)

\begin{tabular}{cccc}
\hline Source & Penjaringan & Gedong and Ciracas & Total \\
\hline Groundwater & 0 & 46.25 & 24.67 \\
Piped water (direct) & 54.29 & 52.5 & 53.34 \\
Piped water (indirect) & 45.71 & 0 & 21.34 \\
Groundwater + piped water (direct) & 0 & 1.25 & 0.67 \\
\hline
\end{tabular}

In Survey B, we found fewer households connected to piped water directly, with only slightly above one fourth of respondents reporting to have a direct piped-water connection, about half of which are in the Southern research site and half in the North. The overall pattern found in Survey A remains. Households in the South combine PDW with piped water or groundwater, while households in Penjaringan predominantly combine PDW with piped water accessed through indirect connections.

Comparing the findings between the northern and southern research sites, we see differences in PDW consumption according to the improved domestic source accessed. Survey A documents that for the $21 \%$ of households from Penjaringan, Gedong, and Ciracas who treat their improved domestic source for drinking instead of buying PDW, the majority of these households prefer groundwater. In Gedong and Ciracas, half of all PDW consumers (76.92\%) combine it with piped water as an improved domestic source, and half with groundwater. The remaining $23.08 \%$ of households-those that do not consume PDW in Gedong or Ciracas-are overwhelmingly those drinking shallow groundwater $(18.27 \%$ versus $3.85 \%$ for piped water). Where groundwater is available and viable, households not drinking PDW are more likely to rely on access to groundwater than on access to piped water. This contrasts with the trend we find in Penjaringan, where use of shallow groundwater is not possible because of its high salinity, so comparatively more households (82.35\%) buy PDW than in the South, which they combine with piped water accessed directly (about 54\%) or indirectly (about $46 \%$, see Table 3). Residents not consuming PDW drink piped water, and are more likely to do so when accessed directly through an in-house or yard connection (10.59\%) than accessed indirectly through neighbors $(7.06 \%)$.

\subsection{Explaining PDW Supply in Indonesia through an Analysis of the Individual}

Using consumer analysis, or a public heath analysis of the individual, our survey results indicate PDW supply is the "choice" of the majority of low-income households in our research sites. If our results are interpreted through these explanatory frameworks, our findings could be investigated as to how they respond to preferences of individuals-taste, perceptions in water quality, perceptions in affordability, convenience. Indeed, research on PDW supply in Indonesia has explored the rationality of the choices made by households, investigating why and how it is perceived as better quality [26,37], more affordable [32], or more convenient [33]. However, we note that these analyses are all still power neutral, as choices are not explained as connected to societal relations.

The dominant understanding of PDW as an a-political consumer choice is reflected in our 2015 interview with a senior official from the National Development Planning Agency (BAPPENAS) responsible for water sector planning,

"We haven't paid a lot of attention to refill water. That is because in Indonesia, households have more than one water source, so we focus on the domestic use. And if the households choose to fulfill their drinking water need through drinking refill water that's a choice, as long as they have enough water supply through an improved source. And, for Jakarta, this is mostly piped water."

As this statement indicates, the criteria currently used to determine whether or not PDW is a consumer choice-irrelevant for development planning-or a "necessity" (and therefore not a choice, and of relevance to inequalities) is access to an improved domestic source. As all the households 
in our survey are considered to have access to an improved domestic source, their consumption of PDW is therefore understood as "consumer choice". These too are the conclusions from water sector development interventions when persistent use of PDW by low income urban households is observed following expansion in access to piped water $[45,46]$. Although there is concern over the water quality of refill PDW [4], the interpretation of PDW supply as a "consumer choice" in the Indonesian water and development sector has removed PDW supply from discussions over water access, and inequalities in access, except in cases where an improved domestic source is not available. This shapes the current development focus on increasing the percentage of population with physical access, without too much attention to the quality of access, as summarized in our interview on water sector development priorities with a World Bank water and sanitation specialist who explains,

"At the moment in Indonesia it is more important to expand access for the people, so people at least have improved water and sanitation services. Whether it has to be potable or not ... I think that's the second layer of priority."

What, then, is the problem with this explanation and the interventions is rationalizes? First, our survey results, and reviews of development interventions, suggest PDW does not go away with access to piped water. We find households do not consume PDW because of a lack of access to an improved domestic source, and consumption of PDW is more likely if they have access to piped water than if they rely on groundwater. The "choice" of PDW supply by low income households is therefore not a "temporary necessity" until access to piped water is provided. However, as we go on to show below, even with access to an "improved domestic source", the "choice" should be seen as an uneven one, shaped by social relations creating inequalities in access, and therefore relevant for a sector concerned with reducing inequalities in access.

\subsection{Towards the Politics of PDW Consumption: Societal Processes and Social Relations}

\subsubsection{Inequalities within Access to Improved Piped Water Domestic Sources}

The classification of piped water as an "improved domestic source" within the Government of Indonesia water and development monitoring framework conceals the heterogeneity of piped water services in Jakarta-continuity, reliability, and quality of water supply differs across the city. This heterogeneity is not a power neutral "gap in service provision", but is shaped by uneven social relations $[14,17,18]$. We focus here on how differences in access within the piped network affect choices for PDW, pointing to how inequalities in the quality of piped water services across the city affect equitable access to safe drinking water.

In previous research, we have documented how in the same survey population in Penjaringan, it is the richest households who are more likely to drink piped water, after point of use treatment, than the poorest households, even though all have some sort of connection to piped water [19]. Richer households are also more likely to have a formal, individual connection to the piped network, whereas poorest households were more likely to have access to the piped network through an indirect connection (nyelang) to a neighbors' connection [19]. These differences in access are relevant for PDW consumption, because they imply different per unit volume costs, and affect reliability and quality of piped water. The price per unit volume of water from an indirect connection is much higher than a formal connection (2.13 USD $/ \mathrm{m}^{3}$ for nyelang vs. $0.38 \mathrm{USD} / \mathrm{m}^{3}$ for formal access) [47], and is less secure. In our conversations with residents in Penjaringan, they reported the price can vary depending on negotiation with one's neighbor, and fluctuates according to demand and supply. The reliability of water supply through an indirect connection also depends on the direct connection from neighbors, whose own reliability fluctuates. In $2015,85 \%$ of households with piped connections in Penjaringan report less than 8 hours of service/day, and only one household had a full 24-hour connection (Survey B). This shows how poorer residents in Penjaringan have a lower level of access to piped water than do better off households, shaping their degree of reliance on—or influencing the rationality of their "choice" for-PDW for safe drinking water supply. 
Maps of low water pressure and hours of continuous service reported by the Jakarta Water Supply Regulatory Board in 2014 [47] indicate poor performance over the majority of Jakarta, but most concentrated in the northern half (Figure 1), where sub-district Penjaringan is located. Our interview with the PT. PALYJA pro-poor service unit staff confirms what we heard from Penjaringan residents- the piped water provider will not add new connections to areas where water pressure cannot be guaranteed. Of course, the low, or negative, water pressure in the underground distribution pipes is also correlated with the quality of piped water, another difference shaping the consumption of PDW by low income residents. All residents in Penjaringan using pipe water rely on household water storage, providing opportunities for recontamination after treatment. Residents report frequent problems with the color of water (brown) and visible dissolved solids, as negative water pressure in a leaky underground distribution system results in infiltration of wastewater.

Differences in piped water pressure and implications for differences in piped water quality has been shown in other cities to shape choices for water treatment options, including PDW $[10,33,48]$. This is highly relevant for Jakarta, where differences in access within the piped network are significant, and $10 \%$ of the total number of piped connections are reported as "zero consumption" due to low water pressure [49]. Although the two private sector service providers for Jakarta state $60 \%$ of households have access to an improved source through piped water [49], this number is contested based on the quality of access provided. Our interview with a senior official in the Ministry of Public Works estimates a much lower service coverage of $39 \%$, while civil society organizations say this is even lower, at $25 \%$ [50]. Both the senior government official and civil society reports highlight that not all areas covered by the piped network receive piped water supply; water pressure is low, and some areas of the network receive only intermittent, or no water supply [47].

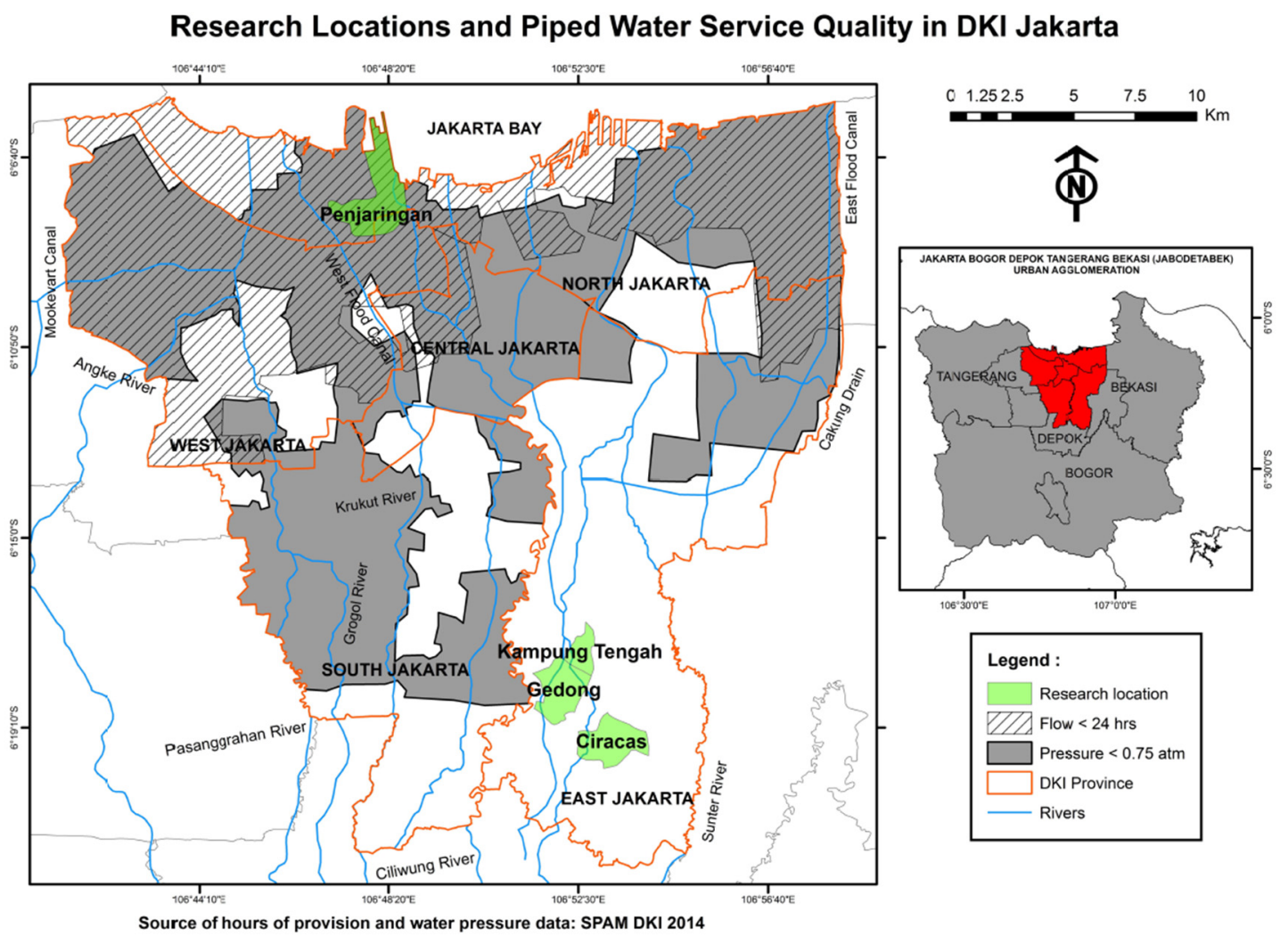

Figure 1. Research locations in North Jakarta (Penjaringan) and East Jakarta (Gedong, Kampung Tengah, Ciracas), and piped water service quality in DKI Jakarta. (Source: Authors)

The unevenness of piped water supply is not power neutral, as it reflects the unevenly experienced impacts of the privatization of water supply in Jakarta and institutional disincentives to serve the 
poorer areas of the city under both public and private operation of the city's piped water supply [51], alongside historically produced socio-spatial inequalities in access to urban services [18]. The design of current urban water sector development interventions in Jakarta suggests uneven social relations still inform sector planning. Previous interventions in improving piped water quality in Jakarta suggest that where the quality of water from piped network will improve first will not be in low income areas. Limited initiatives on improving water quality by the private sector water providers have focused on elite areas of the city, where non-revenue water loss is low, and-perversely-groundwater quality is high (interview with PT. Aetra). Current sector documents identify priorities of flood defense as driving network improvements into areas of high value consumers, who are now abstracting deep groundwater from the contained aquifer [49]. Concerns of the sector regarding the rise in PDW, as discussed with World Bank employees and water service provider staff, are over the permanent loss of high value consumers of piped water, who help utilities to recover costs, rather than concerns with inequalities in access to safe water.

\subsubsection{Inequalities within Access to Improved Groundwater Sources}

Groundwater is the most commonly used improved domestic source across Jakarta: $64 \%$ of households report use of groundwater, and $24 \%$ of households use combinations of groundwater and piped water [2]. Similar to national trends [4], Jakarta achieved its Millennium Development Goal targets for increased access to an improved water source by classifying groundwater as 'improved'. However, like for piped water service, the quality and accessibility of groundwater is highly variable across the city. Our research results indicate how differences in access to shallow sub-surface water for drinking water are shaped by sets of social relations and societal processes, which produce the differently situated choices of individuals for securing safe drinking water.

In Penjaringan, the shallow sub-surface groundwater is saline, reflected in the almost universal use of piped water for domestic uses. In the southern areas of Jakarta, where shallow groundwater is not yet saline, it is likely to be contaminated with e-coli, given the absence of proper wastewater treatment systems in the majority of the city [4]. Fecal coliform can be removed through proper water treatment, such as boiling to provide safe drinking water, although issues of recontamination of stored water after boiling, or proper boiling time, affect safety [37].

In our household survey (Survey A), we find an equal number of the lowest income households in Gedong and Ciracas combine PDW with piped water compared with shallow groundwater. As for piped water, there are differences in access to groundwater; namely, differences in quality, which shape the degree of "choice" for PDW between population groups in Jakarta. First, there are large differences between the fecal and priority chemical contamination found in deep groundwater in the contained aquifer versus the shallow sub-surface groundwater flows. The National Development Planning Agency estimates that $45 \%$ of all groundwater in the shallow sub-surface is contaminated with fecal coliform [52], while the Provincial Environmental Management Agency doubles that estimate, putting it at $90 \%$ [53]. We did not conduct microbiological analysis of shallow groundwater, but we do know that low income urban settlements are much more likely to lack access to sanitation (56\% of poorest urban households versus $90 \%$ of richest urban households) [4] (p. 40), and are more likely to lack access to sanitation providing proper wastewater treatment [4] (p. 15).

Monitoring of the deep groundwater flow system for Jakarta shows contaminated water from the shallow sub-surface does not percolate to the contained aquifer, except in the northern areas of the city, where the recharge system has reversed [54]. We also point to water quality analyses of deep groundwater in the nearby city of Bandung, where groundwater from a depth of 60 meters has the lowest counts of fecal coliform, compared to piped water and shallow groundwater [55]. The superior quality, and reliability, of deep groundwater goes some way to explaining why residents who can afford the high investment and operating costs choose groundwater over piped water. According to PALYJA staff, water supply providers still struggle to convert "key account holders", like commercial housing estates and shopping mall super blocks in central and southern Jakarta, to rely completely on 
piped water, as they prefer to recycle the deep groundwater. Access to the best quality and most secure quantity of groundwater from the contained aquifer is based on affordability, as costs of drilling or operation are not subsidized, and are shaped by other social relations, as political connections enable the illegal use of deep groundwater in northern areas of the city where it is banned [56].

These differences in access to groundwater are produced through historical social inequalities, and are related to inequalities in access to piped water. Therefore, current inequalities in access shaping PDW consumption are produced through historical relationships between piped water, groundwater, and wastewater in the city [14]; "choices" for PDW supply are much more than a response to "temporary" inequalities. Thus, the degree of choice for PDW by individual residents of the city is not evenly distributed, but situated. Some residents have more "choice" due to processes and relations which go beyond their individual capacities, knowledge, and agency.

\section{Discussion: More than Temporary Inequalities}

In this article we have used the case of PDW consumption by low income residents in Jakarta to call attention to the politics currently absent from dominant understandings of this new form of supply. Reviewing existing research on PDW supply by consumer studies and public health, we have shown how approaching PDW through analyses of the individual making the "choice" to consume PDW removes questions of politics and power. This is the result of analytical frameworks, which disconnect choices for safe drinking water from the sociomaterial environments in which choices are made. In turn, this approach to understanding PDW supply curtails investigations into the unevenness of choices, and fails to recognize how impacts of PDW supply on inequalities are situated, with more ambiguous outcomes on access. More practically, for Jakarta, we have shown how this explanation fails to accurately identify who is consuming PDW, why, and for how long this might be the case.

In response, we have illustrated how a framework of situated UPE offers scope to (re)politicize dominant explanations for PDW supply. Specifically, UPE enables a theorization of PDW politics by tracing how uneven societal relations shape the uneven geographies of access and risk, within which individual "choices" are made. For Jakarta, we have illustrated how analyzing PDW through the politics of wider urban water distributions allows for recognition of how choices for how to secure safe drinking water are connected to other flows of water and power. Our analysis of how PDW supply is used in low income settlements, by whom, and in what combinations with other water sources, highlights the historical—not temporary-inequalities in water quantity and quality which PDW supply responds to, and points to the uneven social relations producing these conditions.

Understanding the politics of PDW supply is relevant for water and development sector interventions, especially those implemented under the mandate of SDG 6 to reduce inequalities in access. First, the sector must recognize that the relationship between PDW supply and inequalities in access is more complicated than current binary classifications of PDW as a consumer choice of the middle class, or as a temporary necessity of urban poor residents without access to piped water supply. Rather, the impact of PDW supply on access is situated, depending on the existing environmental inequalities within which it interacts. Reducing inequalities in access to safe water therefore requires interventions to redress power relations, going beyond the tendency to focus on, and leaving responsibility with, individuals.

Understanding the ambiguous impact of PDW supply on inequalities in access is important for Jakarta, but also for other cities where piped water quality has never been safe for drinking. In Indonesia, the current development focus on reducing inequalities by extending access to the network, rather than improving it, will not remove the necessity of PDW, or other treatment options, in the near future. This is especially true given suggestions of how increased supply of PDW is changing perceptions of roles and responsibilities of public water utilities to provide safe drinking water [26].

More broadly, the case of PDW supply in Jakarta underscores the significance of water quality in achieving water equity. PDW trends of increased consumption by low income residents in Indonesian 
cities—and we suspect more globally_illuminate historical inequalities in access to different qualities of water. Ignoring water quality and the social relations which shape uneven geographies of access keeps the responsibility for "safe" water supply with the individual, not the state, and leaves the most responsibility for mitigating the poorest quality of water to those who can least afford it. The revision of the water and development indicators measuring access to water under the Sustainable Development Goals do now include criteria for water quality, and as a result have recognized PDW as a potentially improved source of safe drinking water [25]. The rise in PDW supply emphasizes the need to revisit classifications of improved water sources, and to implement this revision within the development monitoring frameworks of individual countries.

Author Contributions: Conceptualization, M.K. and C.T.W.; methodology, M.K. and C.T.W.; software, C.T.W.; formal analysis, M.K. and C.T.W.; investigation, M.K. and C.T.W.; resources, M.K. and C.T.W.; data curation, M.K. and C.T.W.; writing-original draft preparation, M.K.; writing-review and editing, M.K. and C.T.W.; visualization, C.T.W.; supervision, M.K.; project administration, M.K.; funding acquisition, M.K.

Funding: This research was funded by the Netherlands Ministry of Development Cooperation (DGIS) through the UNESCO-IHE Partnership Research Fund, under the project Uncovering Hidden Dynamics in Slum Environments (UNHIDE). The research was also supported through the project Translating Groundwater Policy to Practice in Jakarta, Indonesia, sponsored by the Netherlands Ministry of Infrastructure and Water Management.

Acknowledgments: This paper draws from a household survey conducted together with research assistants Indrawan Prabaharyaka, Vincent Pooroe, Rochim, Yadi, and Anda. Thanks to Bosman Batubara for his assistance in producing the map of DKI Jakarta water supply.

Conflicts of Interest: The authors declare no conflict of interest. The funders had no role in the design of the study; in the collection, analyses, or interpretation of data; in the writing of the manuscript, or in the decision to publish the results.

\section{References}

1. Badan Pusat Statistik. Household by Region and Primary Source of Drinking Water. 2010. Available online: http:/ / sp2010.bps.go.id/index.php/site/tabel?search-tabel=Household+by+Region+and+Primary+Source+ of+Drinking+Water\&tid=303\&search-wilayah=DKI+Jakarta+Province\&wid=3100000000\&lang=en (accessed on 13 January 2018).

2. Badan Pusat Statistik. Statistik Indonesia 2017. [Statistical Yearbook of Indonesia]; 2017. Available online: https: / /www.bps.go.id/publication/2017/07/26/b598fa587f5112432533a656/statistik-indonesia-2017 (accessed on 27 November 2017).

3. Dewi, N.K. Analysis: Bottled Water Industry Faces Both Growth and Challenges. The Jakarta Post. Available online: http:/ / www.thejakartapost.com/news/2015/05/27/analysis-bottled-water-industry-facesboth-groth-and-challenges.html (accessed on 31 October 2018).

4. World Bank. More and Better Spending: Connecting People to Improved Water Supply and Sanitation in Indonesia-Water Supply and Sanitation Public Expenditure Review (WSS-PER); Water and Sanitation Program, World Bank: Jakarta, Indonesia, 2015.

5. Rodwan, J.G., Jr. Bottled Water 2015: U.S. and International Development and Statistics. International Bottled Water Association, July-August 2016. Available online: http://www.bottledwater.org/public/BWR_ Jul-Aug_2016_BMC\%202015\%20bottled\%20water\%20stat\%20article.pdf\#overlay-context=economics / industry-statistics (accessed on 6 August 2017).

6. Clarke, T. Inside the Bottle: Exposing the Bottled Water Industry; Canadian Centre for Policy Alternatives: Ottawa, ON, Canada, 2007.

7. Hawkins, G.; Potter, E.; Race, K. Plastic Water: The Social and Material Life of Bottled Water; MIT Press: Cambridge, MA, USA, 2015. [CrossRef]

8. Opel, A. Constructing Purity: Bottled water and the commodification of nature. J. Am. Cult. 1999, 22, 67-76. [CrossRef]

9. Race, K. 'Frequent sipping': Bottled water, the will to health and the subject of hydration. Body Soc. 2012, 18, 72-98. [CrossRef]

10. Sharma, A.; Bhaduri, S. Consumption conundrum of bottled water in India: An STS perspective. Bull. Sci. Technol. Soc. 2014, 33, 172-181. [CrossRef] 
11. Bain, R.; Cronk, R.; Wright, J.; Yang, H.; Slaymaker, T.; Bartram, J. Fecal contamination of drinking-water in low-and middle-income countries: A systematic review and meta-analysis. PLoS Med. 2014, 11, e1001644. [CrossRef] [PubMed]

12. Stoler, J. From curiosity to commodity: A review of the evolution of sachet drinking water in West Africa. WIREs Water 2017, 4, e1206.

13. Stoler, J. Improved but unsustainable: Accounting for sachet water in post-2015 goals for global safe water. Trop. Med. Int. Health 2012, 17, 1506-1508. [CrossRef]

14. Furlong, K.; Kooy, M. Worlding water supply: Thinking beyond the network in Jakarta. Int. J. Urban Reg. Res. 2017, 41, 888-903. [CrossRef]

15. Jaglin, S. Être branché ou pas: Les entre-deux des villes du sud [Being connected or not: The in-between of the cities of the South]. Flux 2004, 2, 4-12. [CrossRef]

16. Lawhon, M.; Ernstson, H.; Silver, J. Provincializing urban political ecology: Towards a situated UPE through African urbanism. Antipode 2014, 46, 497-516. [CrossRef]

17. Kooy, M. Developing informality: The production of Jakarta's urban waterscape. Water Alternatives 2014, 7, 35-53.

18. Kooy, M.; Bakker, K. Technologies of government: Constituting subjectivities, spaces and infrastructures in colonial and contemporary Jakarta. Inter. J. Urban Regional Res. 2008, 32, 375-391. [CrossRef]

19. Kooy, M.; Walter, C.T.; Prabaharyaka, I. Inclusive development of urban water services in Jakarta: The role of groundwater. Habitat Int. 2018, 73, 109-118. [CrossRef]

20. Francisco, J.P.S. Why households buy bottled water: A survey of household perceptions in the Philippines. Int. J. Consum. Stud. 2014, 38, 98-103. [CrossRef]

21. Poeradisastra, F. Prospek dan Tren Industri Minuman Ringan Indonesia Memasuki 2012: Urbanisasi dan Kemakmuran? Available online: http:/ / foodreview.co.id/blog-56483-Prospek-dan-PerkembanganIndustri-Minuman-Ringan-di-Indonesia.html (accessed on 16 September 2018).

22. Massoud, M.A.; Maroun, R.; Abdelnabi, H.; Jamali, I.I.; El-Fadel, M. Public perception and economic implications of bottled water consumption in underprivileged urban areas. Environ. Monit. Assess. 2013, 185, 3093-3102. [CrossRef] [PubMed]

23. Rani, B.; Maheshwari, R.; Garg, A.; Prasad, M. Bottled water-A global market overview. Bull. Environ. Pharmacol. Life Sci. 2012, 1, 1-4.

24. Greene, J. Bottled water in Mexico: The rise of a new access to water paradigm. WIRES Water. 2018. [CrossRef]

25. World Health Organization. Safely Managed Drinking Water-Thematic Report on Drinking Water 2017; World Health Organization: Geneva, Switzerland, 2017.

26. Prasetiawan, T.; Nastiti, A.; Muntalif, B.S. 'Bad' piped water and other perceptual drivers of bottled water consumption in Indonesia. WIREs Water 2017, e1219. [CrossRef]

27. Hawkins, G. The impacts of bottled water: An analysis of bottled water markets and their interactions with tap water provision. WIREs Water 2017, 4, e1203.

28. Brei, V.A. How is a bottled water market created? Wiley Interdiscip. Rev. Water 2018, 5, e1220. [CrossRef]

29. Collins, H.; Wright, A. Still Sparkling: The Phenomenon of Bottled Water-An Irish Context. J. Mark. Manag. 2014, 2, 15-31.

30. Viscusi, W.K.; Huber, J.; Bell, J. The private rationality of bottled water drinking. Contemp. Econ. Policy 2015, 33, 450-467. [CrossRef]

31. Wilk, R. Bottled Water: The pure Commodity in the age of branding. J. Consum. Cult. 2006, 6, 303-325. [CrossRef]

32. Walter, C.T.; Kooy, M.; Prabaharyaka, I. The role of bottled drinking water in achieving SDG 6.1: An analysis of affordability and equity from Jakarta, Indonesia. J. Water Sanit. Hyg. Dev. 2017, 7, 642-650. [CrossRef]

33. Nastiti, A.; Muntalif, B.S.; Roosmini, D.; Sudradjat, A.; Meijerink, S.V.; Smits, A.J.M. Coping with poor water supply in peri-urban Bandung, Indonesia: Towards a framework for understanding risks and aversion behaviours. Environ. Urban. 2017, 29, 69-88. [CrossRef]

34. Stoler, J.; Tutu, R.A.; Winslow, K. Piped water flows but sachet consumption grows: The paradoxical drinking water landscape of an urban slum in Ashaiman, Ghana. Habitat Int. 2015, 47, 52-60. [CrossRef]

35. Roekmi, R.A. Safe Water at a Premium. Inside Indonesia. 16 January. Available online: http://www. insideindonesia.org/safe-water-at-a-premium (accessed on 31 October 2017). 
36. Williams, A.R.; Bain, R.E.; Fisher, M.B.; Cronk, R.; Kelly, E.R.; Bartram, J. A systematic review and meta-analysis of fecal contamination and inadequate treatment of packaged water. PLoS ONE 2015, 10, e0140899. [CrossRef] [PubMed]

37. Sima, L.C.; Desai, M.M.; McCarty, K.M.; Elimelech, M. Relationship between use of water from community-scale water treatment refill kiosks and childhood diarrhea in Jakarta. Am. J. Trop. Med. Hyg. 2012, 87, 979-984. [CrossRef]

38. Quansah, F.; Okoe, A.; Angenu, B. Factors affecting Ghanaian consumers' purchasing decision of bottles water. Int. J. Market Stud. 2015, 7, 76-87. [CrossRef]

39. Alda-Vidal, C.; Kooy, M.; Rusca, M. Mapping operation and maintenance: An everyday urbanism analysis of inequalities within piped water supply in Lilongwe, Malawi. Urban Geogr. 2018, 39, 104-121. [CrossRef]

40. Rusca, M.; Boakye-Ansah, A.S.; Loftus, A.; Ferrero, G.; van der Zaag, P. An interdisciplinary political ecology of drinking water quality. Exploring socio-ecological inequalities in Lilongwe's water supply network. Geoforum 2017, 84, 138-146. [CrossRef]

41. Morinville, C. Sachet water: Regulation and implications for access and equity in Accra, Ghana. Wiley Interdiscip. Rev. Water 2017, 4, e1244. [CrossRef]

42. Amsterdam Institute for Social Science Research. AISSR Ethical Review Procedure and Questions. Available online: http:/ /aissr.uva.nl/binaries/content/assets/subsites/amsterdam-institute-for-socialscience-research/map-1/aissr-ethical-review-procedure-and-questions.pdf?1487234676823 (accessed on 24 January 2019).

43. Badan Pusat Statistik. Average Household Size by Province, 2000-2015. 2017. Available online: https:/ /www. bps.go.id/linkTableDinamis/view/id/849 (accessed on 27 November 2017).

44. Deny, S. Tuntut UMP Rp 3,8 Juta Di 2017, Begini Hitungan Buruh. Liputan 6. Available online: http:/ / bisnis.liputan6. com/read/2622371/tuntut-ump-rp-38-juta-di-2017-begini-hitungan-buruh (accessed on 31 October 2018).

45. Fatmawati, V. IUWASH Water Cost Survey: Field Note. Indonesia Urban Water, Sanitation \& Hygiene. News. IUWASH Newsl. 2013, 4, 1-14.

46. Noordegraaf, A. Improving access to clean water by low-income urban communities in Jakarta, Indonesia. Master's Thesis, Department of Geography, Planning and International Development, University of Amsterdam, Amsterdam, The Netherlands, 2016.

47. Badan Regulator Penyediaan Air Minum. Evaluasi Kinerja Pelayanan air Minum Tahun 2014 [Evaluation of the Performance of the Service of Drinking Water by 2014]; Badan Regulator Penyediaan Air Minum: Jakarta, Indonesia, 2015.

48. Nganyanyuka, K.; Martinez, J.; Wesselink, A.; Lungo, J.H.; Georgiadou, Y. Accessing water services in Dar es Salaam: Are we counting what counts? Habitat Int. 2014, 44, 358-366. [CrossRef]

49. Deltares. NCICD: Water Supply Jakarta; Unpublished Document Presented at National Capital Integrated Coastal Development (NCICD) Knowledge Stakeholder Open Workshop; Indonesian Ministry of Public Works: Jkarta, Indonesia, 2017.

50. Zamzami, I.; Ardhanie, N. An End to the Struggle? Jakarta Residents Reclaim Their Water System. In In Our Public Water Future. The Global Experience with Remunicipalisation; Kishimoto, S., Lobina, E., Petitjean, O., Eds.; Transnational Institute: Amsterdam, The Netherlands, 2015; Available online: http: / / www.municipalservicesproject.org/sites/municipalservicesproject.org/files/publications/KishimotoLobina-Petitjean_Our-Public-Water-Future-Global-Experience-Remunicipalisation_April2015_FINAL.pdf (accessed on 18 June 2016).

51. Bakker, K.; Kooy, M.; Shofiani, N.E.; Martijn, E.J. Governance failure: Rethinking the institutional dimensions of urban water supply to poor households. World Dev. 2008, 36, 1891-1915. [CrossRef]

52. Detik. 45\% Air Tanah Jakarta Tercemar E-coli [45\% of Groundwater in Jakarta Contaminated with E-coli]. Detik. Available online: http:/ / news.detik.com/berita/2411711/45-persen-air-tanah-jakarta-tercemar-bakteri-e-coli (accessed on 13 November 2014).

53. Prabowo, D.S. 90 Persen Air Tanah Jakarta Mengandung Bakteri E-coli [90 Percent of Jakarta's Groundwater Contains E-coli Bacteria]. Tribunnews. 2011. Available online: http://www.tribunnews.com/metropolitan/ 2011/06/07/90-persen-air-tanah-jakarta-mengandung-bakteri-e-coli (accessed on 31 October 2018).

54. Deltares. Annex A, B E C: Sinking Jakarta: Annex A, B \&C, Causes \& Remedies; Unpublished Project Report; Deltares: Jakarta, Indonesia, 2016. 
55. Iqbal, M.; Nastiti, A.; Muntalif, B.S. Improved but not always safe: A microbial water quality analysis in Bandung peri-urban households. Presented at the 5th Environmental Technology and Management Conference: Green Technology towards Sustainable Environment, Bandung, Indonesia, 23-24 November 2015.

56. Augustinus, R.B. Understanding the Implementation of Groundwater Regulations and Policies for the Commercial Deep Well Users in Jakarta, Indonesia. Master's Thesis, UNESCO-IHE Institute of Water Education, Delft, The Netherlands, 2016.

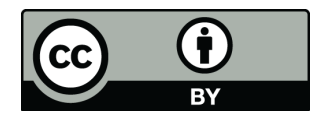

(C) 2019 by the authors. Licensee MDPI, Basel, Switzerland. This article is an open access article distributed under the terms and conditions of the Creative Commons Attribution (CC BY) license (http://creativecommons.org/licenses/by/4.0/). 